\title{
Contents of Volume 5
}

Altchev, T., see S. Nedialkov

Belova, N.F. and I.I. Dmitrichev, Statistics of time use in the USSR

Bonte, J. and P. van Son, Health statistics in the Netherlands for health policy and evaluation: Experience and developments

Bråkenhielm, S., Vegetation and air pollution: Spatial and temporal aspects of sampling in environmental monitoring

Bretz, M., I. Esposito and H. Fleischer, The precision of statistics of international migrations - A study of flows between Italy and the Federal Republic of Germany

Cable, D.R., see D.P. Rose

Češka, J., Annual and multi-annual statistical plans and programmes in Czechoslovakia

Crysdale, J.S., Industrial classification in the Canadian Census of Manufactures: Towards less art and more science

Czajka, B., see J. Kordos

Descy, J.-P. and J.-C. Micha, Use of biological indices of water quality

Dmitrichev, I.I., see N.F. Belova

Donkers, H.W.J., Consumer price indices adjusted for indirect taxes and subsidies in the Netherlands

Doucet, J.E., see E. Outrata

Esposito, I., see M. Bretz

Fleischer, H., see M. Bretz

Góczán, L., A new land evaluation in Hungary based on ecological potential 277

Goldschmidt-Clermont, L., Assessing the economic significance of domestic and related activities

Heinonen, P., see V. Miettinen

Heldal, J., A. Rygh Swensen and I. Thomsen, Census statistics through combined use of surveys and registers?

Iszkowski, J., Annual and multi-year statistical programmes

Janhunen, O., Information technology and statistical product development 
Kahnert, A., Environment statistics in the work programme of the Conference of European Statisticians

Kordos, J., Time use surveys in Poland

Kordos, J. and B. Czajka, Consumer price indices in Poland

Koskimies, $\mathrm{P}$., Trends in bird populations as environmental indicators

Long, J.F. and E.T. Pryor, Comparative demographic effects of Canadian-U.S. immigration flows

Lyberg, L. and B. Sundgren, The impact of the development of EDP on statistical methodology and survey techniques

Micha, J.-C., see J.-P. Descy

Miettinen, V. and P. Heinonen, Use of biocoenosis data in water quality monitoring

Myrberget, S., Hunting statistics as indicators of game population size and composition

Nedialkov, S. and T. Altchev, Development of ecological parameters for use in Bulgarian environment statistics

Nevalainen, K., see R. Shanmugan

Outrata, E. and J.E. Doucet, Impact of new processing techniques on the management and organization of statistical data processing

Potter, H.D., Some conceptual aspects of measuring homogeneity of industrial data from manufacturing censuses and surveys

Pryor, E.T., see J.F. Long

Recknagel, F., A deep expert system for water quality control of lake ecosystems

Rose, D.P., D.R. Cable, R.M. Taylor, W.J. Wallond and P.A. Wake, The impact of new processing techniques on the management of data processing in the United Kingdom Government Statistical Service

Rowntree, J.A., Some recent developments in health service information in England: The Korner Review and Performance Indicators

Schamberger, M., Monitoring wildlife habitat - A critique of approaches 303

Shanmugam, R. and K. Nevalainen, Analysing environmental time series: A review and Finnish case study

Skak-Nielsen, N.V., Marketing of statistical services in Denmark, Iceland and Sweden

Son, P. van, see J. Bonte 
Taylor, R.M., see D.R. Cable

Wahlström, S., Simulating the distribution of economic welfare. The case of Sweden

Wake, P.A., see D.R. Cable

Wallond, W.J., see D.R. Cable 